Rights, Deportation, and Detention in the Age of Immigration Control 



\section{Rights, Deportation, and Detention in the Age of Immigration Control}

Tom K. Wong 


\section{Stanford University Press}

Stanford, California

(C) 2015 by the Board of Trustees of the Leland Stanford Junior University. All rights reserved.

No part of this book may be reproduced or transmitted in any form or by any means, electronic or mechanical, including photocopying and recording, or in any information storage or retrieval system without the prior written permission of Stanford University Press.

Printed in the United States of America on acid-free, archival-quality paper

Library of Congress Cataloging-in-Publication Data

Wong, Tom K., author.

Rights, deportation, and detention in the age of immigration control / Tom K. Wong. pages $\mathrm{cm}$

Includes bibliographical references and index.

ISBN 978-0-8047-9306-3 (cloth : alk. paper)

ISBN 978-0-8047-9457-2 (electronic)

1. Emigration and immigration-Government policy. 2. Emigration and immigration law.

3. Immigrants-Civil rights. 4. Deportation. 5. Alien detention centers. I. Title.

JV6271.W66 2015

$325-\mathrm{dc} 23$

Typeset by Newgen in 10/14 Minion 
For Rose, Soul, Pace, and Ever 
